\title{
Interpersonal Communication of Commercial Sex Workers Transaction with Customers in Syariah Law Area in Indonesia
}

\author{
Nursan Junita \\ Psychology Department, University Malikussaleh, North Aceh, Indonesia \\ Vivi Anggraini \\ BRI Syariah, Jalan Simpang Empat, Lhokseumawe, Indonesia
}

\begin{abstract}
Purpose - The purpose of this study is to get information on how the communication process transaction of commercial sex workers with customer occurs in province that practices Syariah law system.

Design/Methodology/Approach - A qualitative design using phenomenological approach with purposive sampling technique was utilized to obtain data. Subjects were female commercial sex workers with age around 16-45 years. The subjects were from district Banda Sakti and Muara Dua Lhokseumawe.

Findings - The result of study showed that subjects used interpersonal communication of self-disclosure through social media communication which was supported by verbal and non-verbal communication that gives an equal reaction. The type of communication used by commercial sex workers during the process of transactions were through face to face and media communication. However, it was found some barriers that interfere while doing interpersonal communication during the transaction, such as adjustment problem of subject, an error communication, and misperception between the subject and the customer that used their services.

Research Limitations/Implications - The study only focuses on how communication process of transaction occurs; therefore, it is important to do further research that focuses on how the Syariah law system impacts psychological attitudes toward commercial sex workers and how it will reduce the activity of commercial sex workers in Aceh, as well as how the communication occurs between parent and child that contribute them to become a commercial sex worker.

Practical Implications - Government should prevent commercial sex workers increase in Aceh as well as parents should more aware about their children's activities outside home and be more communicative with their children.

Originality/Value - This paper gives information to the Aceh government to make further decision making and implement Syariah law system consistently and with commitment.

Keywords Communication, interpersonal communication, commercial sex workers, transaction, customer

All papers within this proceedings volume have been peer reviewed by the scientific committee of the Malikussaleh International Conference on Multidisciplinary Studies (MICoMS 2017).
\end{abstract}

(C) Nursan Junita, Vivi Anggraini. Published in the Emerald Reach Proceedings Series. Published by Emerald Publishing Limited. This article is published under the Creative Commons Attribution (CC BY 4.0) licence. Anyone may reproduce, distribute, translate and create derivative works of this article (for both commercial and non-commercial purposes), subject to full attribution to the original publication and authors. The full terms of this licence may be seen at http://creativecommons.org/ licences/by/4.0/legalcode

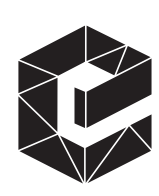

Emerald Reach Proceedings Series Vol. 1 Emerald Publisp. 151-155 2516-2853 DOI 10.1108/978-1-78756-793-1-00057 
Proceedings of MICoMS 2017

\section{2}

\section{Introduction}

Lhokseumawe is located in the northern part of Aceh province. It is known as the province that implemented and applied Syariah law. Most people are Muslims where women use hijab as their self-identity as a Muslim. Lhokseumawe was once known as the city of "Petro Dollars" as the city produced gas, but now it has become commercial sex workers. In fact, based on field observation, there were two districts; Banda Sakti and Muara Dua as the stopover and meeting point for transaction between commercial sex workers and customers. The area of transaction in Banda Sakti district were at KP3 Lhokseumawe Cafe, Ariski Cafe, Shakira Cafe, 55 café, and Sentosa café, whereas the area of Muara Dua district were at Muara Cafe, Seroja Café, Idaman Cafe, and Singapore Cafe.

Based on data obtained from Komisi Penanggulangan AIDS (KPA), Lhokseumawe (2009) stated that Aceh Tamiang was the first center of commercial sex workers followed by Lhokseumawe, Banda Aceh, West Aceh, and Aceh Besar. The percentage of commercial sex workers in Lhokseumawe is as much as $18 \%$ based on recapitulation of hotspot and key population data collection on January 24-26, 2012. In fact, free sex has contributed to the transmission of $\mathrm{HIV}$ and AIDS virus to reach $65 \%$ overall. This is because there are still places where prostitution is done secretly and confidentially. This is also in line with news about conducting raids on immoral locations by residents at Lhokseumawe (Mardani, 2017). The Lintas National news also reported about the police conducting raids on suspected sites in Lhokseumawe (Fazil, 2017). The reality of the problem is that the presence of local commercial sex workers has increased as much as $65 \%$ at Lhokseumawe. The data from KPA Lhokseumawe (2009) showed that the total number of commercial sex workers were 51. It is divided into two types, which were direct commercial sex workers (work as the main job) as 37 people and indirect commercial sex workers (work not as the main job) as 14 people. It increased in 2012 to 43 people of direct commercial sex workers and 21 indirect commercial sex workers.

However, the phenomenon above could contribute for social problem and negative impact toward young generation. The case of sex workers increases every year. How does this happen in Aceh that implements the syariah laws system? Therefore, in this study I would like to know the interpersonal communication patterns used by commercial sex workers in the process of transaction with customer as well as the barriers of communication interpersonal of commercial sex workers. The transaction process begins with a mutual acquaintance through "Germo," from friend who became the agent and even some were from customer to customer. Then, sex workers sit together at one table, enjoying dinner and sing a song with customer. Commercial sex workers wear tight clothes and excessive make up. They used nonverbal communication of body language movement and facial expression to communicate. Then, leave the cafe together. They used media communication such as hand phone and social media such as facebook. Therefore, based on the above phenomenon, it is interested in conducting research on interpersonal communication of commercial sex workers transactions with customers in law area of Indonesia.

\section{Research Problem}

The research problem in this study are: (a) How is interpersonal communication used by commercial sex workers in the process of transactions and (b) the barriers of interpersonal communication that occurs in the process of transactions between commercial sex workers and the customer.

\section{Research Objective}

The objectives of this research are: (a) to know and describe the interpersonal communication that is used by commercial sex workers in the process of transaction and (b) 
know and describe the interpersonal communication barriers that occur in the process of transactions between commercial sex workers with customers.

\section{Methods}

The research approach used in this study is the qualitative method using phenomenological approach. Subjects were female sex workers with age around 16-45 years. The subject from residence in Lhokseumawe. Data retrieval technique using the technique of "purposive sampling." Data collection techniques were conducted through observation techniques, interviews, and documentation. Data analysis techniques in this study used qualitative data analysis techniques from the very beginning until the completion of data collection.

\section{Result and Discussion}

\subsection{Interpersonal communication form of commercial sex workers in transaction with customers}

It is clearly found that each subject has their own style or form of communication during the process of interaction with customer. Each subject used interpersonal communication of self-disclosure through media communication, verbal, and nonverbal language to get attraction with customer. So that it helped subject and customer easily in doing transaction process. However, the openness is only limited to the superficial things. Subjects were very reluctant to open about their personal life. But if the subject can trust the customer they are not reluctant to talk about their personal life.

Karina was able to build up a good rapport with customer, so that the customer became comfortable with her. Her courtesy and elegancy in the process of communication both verbally and nonverbally made the customer attracted. Flower is not really open in the process of communication to reveal about her personal life to the customer. Only to the customers whom she can trust. However, in the process of communication with customers, her self-disclosure is weak, she is not good in building up a relationship. Although there is an openness between customer, but it does not build up a closed interpersonal relationship. Silvia was able to communicate with customers as well as Karina. But Silvia look childish and not matured. Therefore, she likes to talk and express about her feelings easily with her trusted customer, this kind of self-disclosure make her easy to express his feelings because it makes her happy. Rani is also able to communicate openly with her customer. She is easy to share and express about her feeling as well as discuss about her problem with her customer to get the solution. Her openness of self-disclosure about her personal information will give a positive stimulus toward the customers. Memel more attractive in process of communicating with customer, so that customers feel comfortable and interest to use Memel services. Memel is not only good in build-up interpersonal communication relationship but also keep the performance well in order to get attraction from the customer.

All the subjects were able to find a style and form of interpersonal communication that suited with their personality in build up a relationship with customers. The researcher found that the development of relationships with self-disclosure is one of the main medium in the process of communication for transaction with customer. However, self-disclosure is not only the way to build-up interpersonal communication but also physical attraction. Commercial sex workers who are physically attractive have a great opportunity to get customers. Moreover, if the sex workers have a hospitality, friendly, and enough knowledge, these would make the customer feel comfortable during interaction with them. Karina, Flowers, Silvia, Rani, and Memel are obviously having an age gap, which certainly can affect their performance in the presence of customers. Memel of 30 years always trying to keep the body shape, skin, hair, and put make up in her face. A young Karina who is 
Proceedings of MICoMS 2017

\section{4}

energetic and naturally stunning, does not afraid of her appearance. Karina is still 22 years old simply use the make up with natural and minimalist. Flower, with 27 years old, has naturally beauty, so not really spend much money for her skin care. She put sensual make up in the face during her work. In contrast, with Silvia the young teenage who maintain her appearance by using a good clothes, accessories, and perfume. Rani is also a very young lady. She does not have difficulty for maintaining her appearance. Make up become her major concern without using in excessive. Memel who are age 30 years had a strong challenge to continue to take care of her body in order to remain confident in front of customer. All these things make them become confidence in communication during the process of transaction.

\subsection{The barriers of interpersonal communication of commercial sex workers in process of transactions with customer}

It was found that interpersonal communication barriers experienced by Karina was when she is having a hard time or a problem that makes her emotionally condition disturb and distress. In this condition, she experienced difficulty to focus during the process of communication with customer. Flower, often failed during the process of transaction due to her interpersonal communication problem. She is not a person who is easy to interact with people. It also could be influenced by her worries about her work, and if the family knew about her real identity. Therefore, subject always trying to ask help from her agent namely " $F$ " to assist her in the process of transactions with customers who want to use her service. Silvia has a problem when she did not get permission from her parents to leave the house. This often makes customers upset. Silvia also often replace her phone with new numbers, so that parent do not suspect her profession. But this create a misunderstanding between her and customer. However, Silvia experienced difficulty when meeting with customers who aged above her age. She difficulty to understand the symbol of verbal or nonverbal language that made her difficult to understand the intention of the customers.

Rani has difficulty when the customer wants to use her services suddenly, while she was at campus. The difficulty was when she did not get permission from the lecture to leave the class earlier. Sometimes she used excuse of illness, but it did not work anymore. Consequently, she will loss the opportunity to earn money. Rani is also a kind of person that not easy to make friends, because Rani did not want her friend to know about her profession and suspected. Rani never uses her real name. It also become a problem when the customers want to use her services again or when customers recommended her to new customers. Rani prefers to use social network "face book" to communicate with the customer. Sometimes Rani also found problems in understanding the written expression from customer that led to misperception of the meaning.

Memel experiences communication barriers, when her condition is physically weak. She has medical problem of epilepsy that causes her difficulty in concentration and listening during the process of communication with customers, so that customers may feel uncomfortable. Moreover, when Memel suffered from emotional distress and was unable to control her emotional reaction during the process of communication that led to loose her customer.

\section{Conclusion}

It is concluded that commercial sex workers build up interpersonal communication process of self-disclosure with their customers by face-to-face and media communication during the transaction. They also build up the process of rapport which ends with the transaction. However, commercial sex workers prepared themselves before meeting with customers by 
applying make-up on face, use perfumes that smell attractive for men, and wear clothing that is fashionable. Furthermore, face-to-face communication will help sex workers focus on the customer in order to understand the conversation that is discussed by the customer. If the customer gives feedback, then commercial sex workers will give their contact number to continue their interpersonal communication with customers.

Indeed, the commercial sex worker that use media communication was introduced by agent to customer by giving their mobile contact and social network. Sometimes introduced by friend to friend or customer's recommendation by giving a contact person or social networking account. However, the proses of self-preparation to meet customer was similar to those who performed by the transaction face to face.

The barriers that occurred with interpersonal communication of commercial sex workers who use face-to-face communication is the adjustment in the first meeting. Body language greatly affects the success or failure of transaction, as well as dress performance, perfume taste, and make up use all become contributing factors for success or failure of transaction. While the barriers of media communication used by sex workers because of lack of interpersonal communication caused difficulty during the meeting, sex workers look more attractive when using the media because they don't have to be face to face. But the problem happens when they meet each other. This creates an uncomfortable situation and discomfort in the process of communication with the customer as well as the process of transaction.

\section{References}

Fazil, M. (2017). Lintasnasional.com. (Online), http://www.lintasnasional.com/polisi-gerebek-rumahdiduga-lokasi-prostitusi-di-lhokseumawe/ . 17 Oktober 2017.

Komisi Penanggulangan AIDS (KPA) kota Lhokseumawe, (2009). Pendataan Hotspot dan Populasi kunci wanita pekerja seks komersial kota Lhokseumawe. Lhokseumawe-North Aceh.

Komisi Penanggulangan AIDS (KPA) kota Lhokseumawe, (2012). Pendataan Hotspot dan Populasi kunci wanita pekerja seks komersial kota Lhokseumawe. Lhokseumawe-North Aceh.

LittleJohn, S.W. (2009). Teori Komunikasi. Salemba Humanika, Jakarta.

Mardani. (2017). Merdeka.com, (Online), https://www.merdeka.com/peristiwa/warga-lhokseumawegerebek-lokasi-maksiat.html. 24 Februari 2017.

\section{Corresponding author}

Nursan Juwita can be contacted at nursan73@gmail.com 